\title{
A Case of Subclinical Hypothyroidism Developing Marked Pleural Effusions and Peripheral Edema with Elevated Vascular Endothelial Growth Factor
}

\author{
YUJI HATAYA*,**, TAKASHI AKAMIZU***, NAOTETSU KANAMOTO*, KENJI MORIYAMA*, \\ AKIRA SHIMATSU\# AND KAZUWA NAKAO* \\ *Department of Medicine and Clinical Science, Kyoto University Graduate School of Medicine, Kyoto 606-8507, Japan \\ **Department of Endocrinology and Metabolism, Shizuoka City Hospital, Shizuoka 420-8630, Japan \\ ***Translational Research Center, Kyoto University Hospital, Kyoto 606-8507, Japan \\ ${ }^{\#}$ Clinical Research Institute for Endocrine Metabolic Disease, Kyoto Medical Center, Kyoto 612-8555, Japan
}

\begin{abstract}
A 69-year-old woman was admitted for the treatment of marked pleural effusions and peripheral edema. Analytical studies of the pleural effusion revealed exudates. Culture for bacterial organisms and tuberculosis were negative, and cytology was normal. She had a mediastinal tumor at the age of 61 and regular follow-up showed no evidence of malignancy. She underwent the mediastinal tumor resection, because we thought this was the cause of her symptoms. However, her clinical symptoms persisted after surgery. Next, we noticed subclinical hypothyroidism, in which serum TSH level was elevated with concomitant normal thyroid hormone levels. In addition, serum vascular endothelial growth factor (VEGF) levels, which have been reported to be related to the pathophysiology of the extravascular volume overload, were elevated. Although her TSH level was slightly elevated $(15.4 \mu \mathrm{U} / \mathrm{ml})$, we started thyroid hormone replacement therapy. This therapy gradually ameliorated her clinical manifestation and abnormal laboratory data, including elevated VEGF levels. These observations indicate that even subclinical hypothyroidism may cause severe clinical manifestations. Furthermore, elevated VEGF may be a contributing factor in the pathogenesis of extravascular volume overload in hypothyroid patients.
\end{abstract}

Key words: Primary myxedema, Hypothyroidism, VEGF, Estradiol, Pleural effusion

(Endocrine Journal 54: 577-584, 2007)

SUBCLINICAL hypothyroidism is defined as a condition with an elevated TSH and normal free $\mathrm{T}_{4}\left(\mathrm{FT}_{4}\right)$, despite the confusing nomenclature [1-3]. The overall prevalence has been reported to range from $4 \%-10 \%$ in large general population screening surveys and from $7 \%-26 \%$ in studies of the elderly [1]. The condition may be associated with cardiac dysfunction, increased risk for the development of atherosclerosis, elevation in total and low-density lipoprotein (LDL) cholesterol, systemic hypothyroid symptoms, neuropsychiatric

Received: June 29, 2006

Accepted: March 28, 2007

Correspondence to: Yuji HATAYA, M.D., Ph.D., Department of Endocrinology and Metabolism, Shizuoka City Hospital, 10-93 Ootemachi, Aoi-ku, Shizuoka 420-8630, Japan symptoms, and progression to overt, symptomatic hypothyroidism [3]. The measurement of TSH is the most sensitive test for early diagnosis of primary hypothyroidism; however, TSH may be a poor measure for estimating the clinical and metabolic severity of overt hypothyroidism [4].

Effusions in serous body cavities, including peritoneal, pleural and pericardial, are frequently recognized in hypothyroidism [5,6]. Although increased capillary permeability with leakage of plasma proteins was reported in hypothyroid patients [7], the mechanism by which these effusions develop is not well understood. Vascular endothelial growth factor (VEGF) is an angiogenic and mitogenic substance that seems to be active in vascular endothelial cells [8-10] and plays an important role in tumor growth and in the metastatic 
process [11]. VEGF is also known as a vascular permeability factor and induces a rapid and reversible increase in vascular permeability $[12,13]$. Recently, an association of edema with increased VEGF levels has been demonstrated in many pathological conditions, such as POEMS (polyneuropathy, organomegaly, endocrinopathy, M-protein and skin changes) syndrome [14], ovarian hyperstimulation syndrome [15], preeclampsia [16], and diabetic patients with troglitazone treatment [17].

Here we report a case of primary hypothyroidism with severe clinical manifestations, though the biochemical thyroid function showed subclinical hypothyroidism. She had marked pleural effusions and peripheral edema, with elevated VEGF.

\section{Case Report}

A 69-year-old woman suffered from cough and dyspnea in June 2000 and bilateral pleural effusion was observed. Her past medical history included the following conditions. At 37 years of age she underwent a total hysterectomy for rupture of the uterus during labor. She had no history of estrogen treatment. At the age of 50, she developed leg edema; however, she ignored the condition. At 61, she had a mediastinal tumor and regular follow-up showed no evidence of malignancy.

She was hospitalized for the treatment of pleural effusions in thoracic surgery in our hospital in July 2000. Chest radiography demonstrated massive bilat- eral pleural effusions (Fig. 1A) and echocardiography showed pericardial effusions. Analytical studies of the pleural effusion revealed exudates with protein $3.6 \mathrm{~g} /$ $\mathrm{dL}$ and cell count of $400 / \mathrm{mm}^{3}$. Lymphocytes were predominant (90\%). Culture for bacterial organisms and tuberculosis were negative and cytology was normal. F-18-fluorodeoxyglucose positron emission tomography (FDG-PET) showed a high-uptake lesion, which coincided with the anterior mediastinal tumor but no other abnormal uptake could be found. In August, she underwent both mediastinal tumor and pericardium resection. The pathological report of the surgical specimen was consistent with a benign thymoma of the noninvasive type. Her clinical symptoms persisted after surgery and it was noticed that this was not the cause of her symptoms.

After consultation with our peers, the possibility of hypothyroidism as a cause of her symptoms was considered. On physical examination, she had anasarca with pretibial pitting edema on her legs (Fig. 2A). Laboratory data showed mild decreased total protein and albumin levels (Table 1). Total cholesterol (T-Cho) and creatine kinase (CK) levels were within normal limit. Her thyroid function revealed subclinical hypothyroidism, such as slightly elevated $\mathrm{TSH}$, and both free $\mathrm{T}_{3}\left(\mathrm{FT}_{3}\right)$ and $\mathrm{FT}_{4}$ within normal range (Table 2). $\mathrm{FT}_{3}$ and $\mathrm{FT}_{4}$ were measured by immunoradiometric assays (Daiichi Radioisotope Laboratories Ltd., Tokyo, Japan). Antithyroid peroxidase antibodies, antithyroglobulin antibodies and anti-TSH receptor antibodies were all negative. Thyroid ultrasound examination demonstrated an atrophic thyroid gland, with multiple
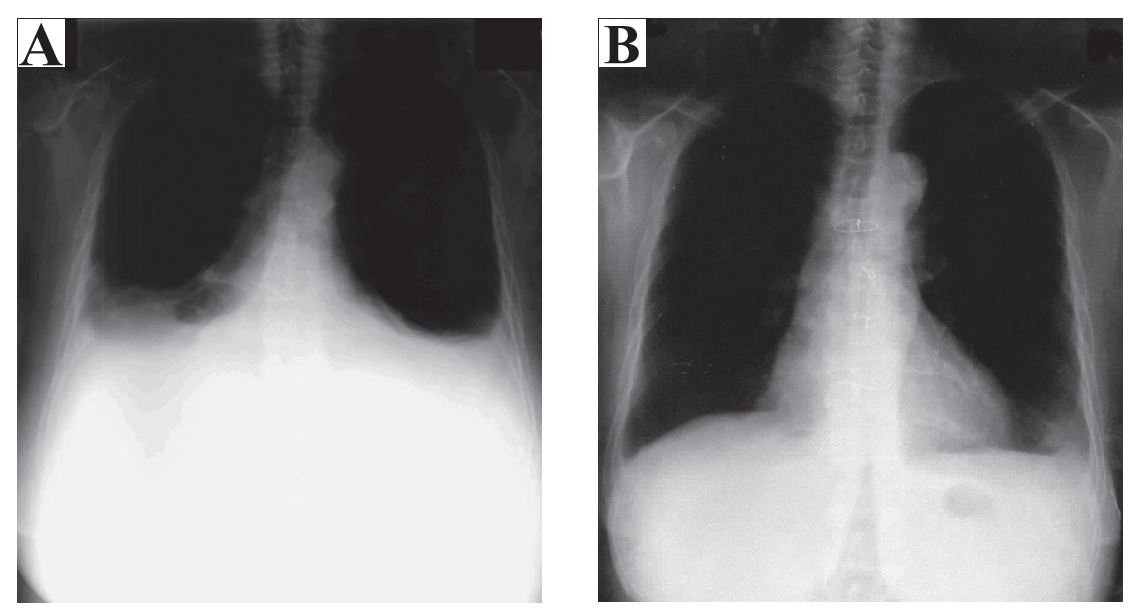

Fig. 1. Posteroanterior chest roentgenogram. A, in August 2000, demonstrating massive bilateral pleural effusions. B, in April 2001, demonstrating resolution of pleural effusions. 
cysts in the thyroid. ${ }^{99 \mathrm{~m}} \mathrm{Tc}$ pertechnetate thyroid scintigraphy showed a normal thyroid shape with even trapping and a normal uptake ratio $[2.5 \%$ (normal range, $0.4-3.0 \%)$ ]. Another endocrinological examination is shown in Table 2. Serum LH and FSH levels were $0.83 \mathrm{mIU} / \mathrm{mL}$ and $10.6 \mathrm{mIU} / \mathrm{mL}$, with estradiol

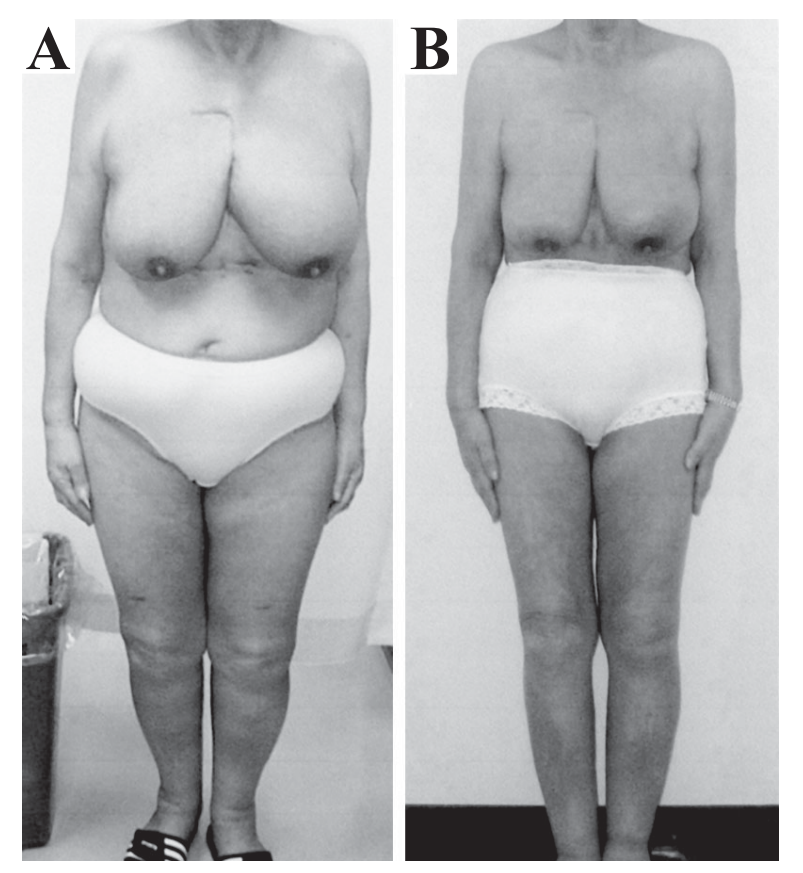

Fig. 2. A, Patient presented with marked peripheral edema in September 2000. B, Peripheral edema was improved after thyroid hormone replacement therapy in March 2001 .
(E2) of $55 \mathrm{pg} / \mathrm{mL}$.

Initially, we suspected POEMS syndrome because she had marked pleural effusions and peripheral edema, even though her thyroid function showed a normal $\mathrm{FT}_{4}$ and slightly elevated TSH. Furthermore, she had elevated E2 in spite of being postmenopausal. To evaluate polyneuropathy, motor nerve conduction velocity was performed, but was normal in both lower extremities. Abdominal computerized tomography scan showed a slightly enlarged liver, but neither splenomegaly nor apparent tumor lesion was found. Though serum $\mathrm{IgG}$ level was increased to $2185.7 \mathrm{mg} / \mathrm{dL}$ (normal range, $788.0-1841.0 \mathrm{mg} / \mathrm{dL}$ ), serum immunoelectrophoresis did not reveal the possibility of IgG monoclonal protein, and bone marrow aspiration specimen showed no abnormality. Serum VEGF and interleukin6 (IL-6) levels, which have been reported to increase in POEMS syndrome, were increased to $2289.9 \mathrm{pg} / \mathrm{mL}$ (normal range, $62.0-707.0 \mathrm{pg} / \mathrm{mL}$ ) and $7.3 \mathrm{pg} / \mathrm{mL}$ (normal range, $<4.0 \mathrm{pg} / \mathrm{mL}$ ), respectively.

\section{Clinical course of the patient}

The patient did not have evidence of polyneuropathy, which was observed in $100 \%$ of POEMS syndrome [18]. In view of this, POEMS syndrome was ruled out. Though there was a slight elevation in TSH level, we started her on thyroid hormone replacement therapy. Levothyroxine sodium $\left(\mathrm{T}_{4}\right)$ was used at a dose of $25 \mu \mathrm{g}$ /day from September and then gradually in-

Table 1. Laboratory data

\begin{tabular}{|c|c|c|c|c|c|}
\hline \multicolumn{2}{|c|}{ Blood cell count } & \multirow{2}{*}{$\begin{array}{c}\text { Normal range } \\
2700-8500\end{array}$} & \multicolumn{2}{|c|}{ Blood chemistry } & \multirow{2}{*}{$\frac{\text { Normal range }}{13-33}$} \\
\hline WBC & $12000 / \mu \mathrm{l}$ & & AST & $22 \mathrm{IU} / 1$ & \\
\hline $\mathrm{RBC}$ & $352 \times 10^{4} / \mu 1$ & 319-494 & ALT & $11 \mathrm{IU} / 1$ & $6.0-27.0$ \\
\hline $\mathrm{Hb}$ & $11.5 \mathrm{~g} / \mathrm{dl}$ & $10.2-14.9$ & ALP & $238 \mathrm{IU} / 1$ & $115-359$ \\
\hline \multirow[t]{4}{*}{ PLT } & $66.2 \times 10^{4} / \mu \mathrm{l}$ & $11.0-34.7$ & $\mathrm{TP}$ & $6.1 \mathrm{~g} / \mathrm{dl}$ & $6.3-8.1$ \\
\hline & & & Alb & $3.0 \mathrm{~g} / \mathrm{dl}$ & $3.9-5.1$ \\
\hline & & & T-Cho & $161 \mathrm{mg} / \mathrm{dl}$ & $140-220$ \\
\hline & & & Triglyceride & $194 \mathrm{mg} / \mathrm{dl}$ & $34-173$ \\
\hline \multicolumn{2}{|c|}{ Urine } & & CPK & $36 \mathrm{IU} / 1$ & $35-141$ \\
\hline Protein & $(-)$ & & BUN & $10 \mathrm{mg} / \mathrm{dl}$ & $8.0-22.0$ \\
\hline Glucose & $(-)$ & & CRE & $0.7 \mathrm{mg} / \mathrm{dl}$ & $0.4-0.8$ \\
\hline Ketone & $(-)$ & & $\mathrm{Na}$ & $132 \mathrm{mEq} / \mathrm{l}$ & $136-144$ \\
\hline \multirow[t]{5}{*}{ O.B. } & $(-)$ & & $\mathrm{K}$ & $3.5 \mathrm{mEq} / \mathrm{l}$ & $3.6-4.8$ \\
\hline & & & $\mathrm{Cl}$ & 90 mEq/l & 99-109 \\
\hline & & & Glu & $107 \mathrm{mg} / \mathrm{dl}$ & $78-110$ \\
\hline & & & $\mathrm{HbAlc}$ & $5.0 \%$ & $4.8-5.8$ \\
\hline & & & CRP & $0.8 \mathrm{mg} / \mathrm{dl}$ & $<0.2$ \\
\hline
\end{tabular}


Table 2. Endocrinological examination

\begin{tabular}{lcllcc}
\hline & Reference interval & & \multicolumn{3}{c}{ Reference interval } \\
\hline $\mathrm{TSH}$ & $15.4 \mu \mathrm{U} / \mathrm{ml}$ & $0.41-4.0$ & LH & $0.83 \mathrm{mIU} / \mathrm{ml}$ & $4.2-79.6$ \\
$\mathrm{FT}_{3}$ & $2.97 \mathrm{pg} / \mathrm{ml}$ & $2.0-4.9$ & FSH & $10.6 \mathrm{mIU} / \mathrm{ml}$ & $12.6-235.7$ \\
$\mathrm{FT}_{4}$ & $1.16 \mathrm{ng} / \mathrm{dl}$ & $0.82-1.63$ & Estradiol & $55 \mathrm{pg} / \mathrm{ml}$ & $<16$ \\
$\mathrm{TPOAb}$ & $<0.3 \mathrm{U} / \mathrm{ml}$ & $<0.3$ & Testosterone & $0.27 \mathrm{ng} / \mathrm{ml}$ & $0.13-0.69$ \\
$\mathrm{TgAb}$ & $<0.3 \mathrm{U} / \mathrm{ml}$ & $<0.3$ & $17 \alpha-O H P$ & $0.2 \mathrm{ng} / \mathrm{ml}$ & $0.1-3$ \\
$\mathrm{TRAb}$ & $7.9 \%$ & $<15$ & DHEA-S & $774 \mathrm{ng} / \mathrm{ml}$ & $50-1000$ \\
$\mathrm{ACTH}$ & $11.9 \mathrm{pg} / \mathrm{ml}$ & $7-56$ & & Urinary hormone excretion & \\
$\mathrm{Cortisol}$ & $10.2 \mu \mathrm{g} / \mathrm{dl}$ & $5.0-15.0$ & $17-$ OHCS & $3.5 \mathrm{mg} /$ day & $2.2-7.3$ \\
$\mathrm{GH}$ & $1.7 \mathrm{ng} / \mathrm{ml}$ & $0.17-1.41$ & $17-\mathrm{KS}$ & $3.4 \mathrm{mg} /$ day & $2.4-11.0$ \\
$\mathrm{IGF}-\mathrm{I}$ & $25 \mathrm{ng} / \mathrm{ml}$ & $121-436$ & Estradiol & $6 \mu \mathrm{g} / \mathrm{day}$ & $<2.1$ \\
$\mathrm{PRL}$ & $11.3 \mathrm{ng} / \mathrm{ml}$ & $1.0-13.9$ & & & \\
\hline
\end{tabular}

17 $\alpha$-OHP: $17 \alpha$-hydroxy progesterone, DHEA-S: dehydroepiandrosterone sulfate, 17-OHCS: 17-hydroxy corticosteroid, 17-KS: 17-ketosteroid
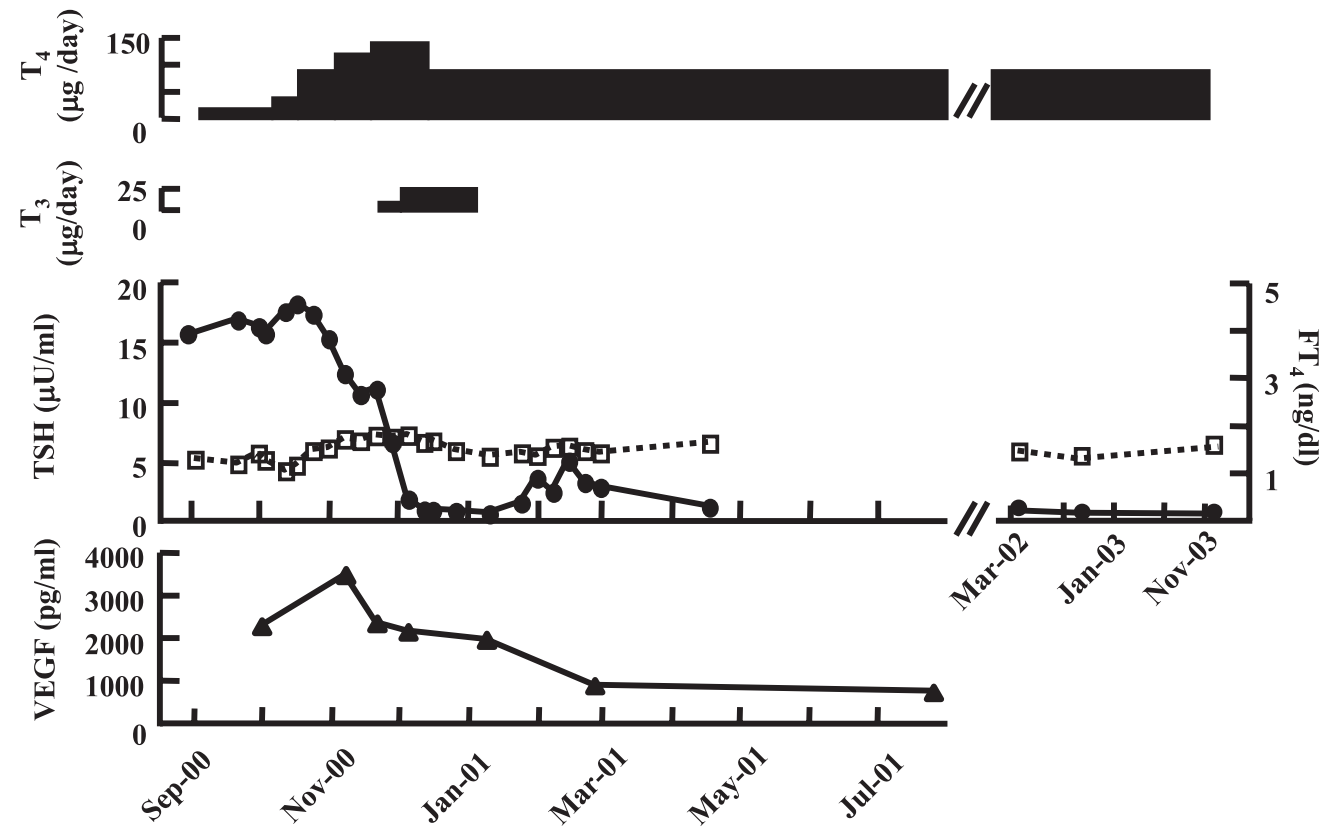

Fig. 3. Changes in $\operatorname{TSH}(\bullet), \mathrm{FT}_{4}(\square)$ and VEGF $(\boldsymbol{\Delta})$ concentrations over time. Thyroid hormone treatment is indicated by the upper graph.

Table 3. Changes in TSH, gonadotropin, E2 and cytokines

\begin{tabular}{lccccccc}
\hline & Oct 2000 & Nov & Dec & Jan 2001 & Feb & Jul & Reference interval \\
\hline TSH $(\mu \mathrm{U} / \mathrm{ml})$ & 15.4 & 12.0 & 0.25 & 0.04 & 2.7 & & $0.41-4.0$ \\
LH $(\mathrm{mIU} / \mathrm{ml})$ & 0.83 & & 37.0 & 28.9 & & 30.0 & $>4.2$ \\
FSH $(\mathrm{mIU} / \mathrm{ml})$ & 10.6 & & 49.0 & 47.0 & & 78.0 & $>12.6$ \\
E2 $(\mathrm{pg} / \mathrm{ml})$ & 55 & 42 & 19 & $<16$ & & $<16$ & $<16$ \\
VEGF $(\mathrm{pg} / \mathrm{ml})$ & 2289.9 & 3492.6 & & 1974.0 & 896.6 & 754.8 & $62-707$ \\
IL-6 $(\mathrm{pg} / \mathrm{ml})$ & 7.3 & & & 5.7 & & 1.6 & $<4.0$ \\
\hline
\end{tabular}


creased to $150 \mu \mathrm{g} /$ day. Because her TSH had not been normalized by $150 \mu \mathrm{g} /$ day $\mathrm{T}_{4}$, liothyroninesodium $\left(\mathrm{T}_{3}\right)$ was added at a dose of $8.3 \mu \mathrm{g} /$ day in addition to $\mathrm{T}_{4}$ from November and then gradually increased to $25 \mu \mathrm{g} /$ day. In December, her TSH moved into normal range, and thereafter TSH and thyroid hormone levels were maintained within normal range at a dose of only $100 \mu \mathrm{g} /$ day $_{4}$ (Fig. 3).

Pleural effusions and peripheral edema were remarkably improved after the decrease of TSH (Fig. 1B, 2B). In addition, the abnormality of LH, FSH and E2 were ameliorated following the improvement of thyroid function (Table 3). Similarly, VEGF and IL-6 levels were decreased. Almost all symptoms and signs were improved after thyroid hormone replacement therapy. Her clinical condition has remained stable for several years.

\section{Discussion}

The biochemical state characterized by an elevated serum TSH level with a concomitant normal $\mathrm{FT}_{4}$ level has received a variety of designations, including mild thyroid failure, as well as compensated, early, latent, mild, minimally symptomatic, and preclinical hypothyroidism [2]. The most widely applied designation for this biochemical state is subclinical hypothyroidism, despite the fact that the meaning is somewhat ambiguous [1-3]. Although it is commonly believed that subclinical hypothyroidism usually represents mild clinical signs, our patient had severe clinical manifestations such as marked pleural effusions and peripheral edema. Pleural effusions have been reported to be associated with the duration rather than the degree of biochemical hypothyroidism [6, 19]. Furthermore, tissue hypothyroidism at the peripheral target organs may be different in the individual patient. Zulewski et $a l$. showed that some patients with severe biochemical hypothyroidism had only mild clinical signs, whereas other patients with minor biochemical changes had quite severe clinical hypothyroidism [20]. On the other hand, although her thyroid function showed slightly elevated TSH, she needed $100 \mu \mathrm{g} /$ day $\mathrm{T}_{4}$ to maintain TSH within normal range, which is the dosage usually used for moderate to severe hypothyroid patients. TSH measurement has a high diagnostic accuracy for the early detection of primary hypothyroidism. However, TSH may be a poor measure of the clinical and meta- bolic severity of hypothyroidism, because TSH is maximally stimulated in the early stages of primary thyroid failure, with no further increase occurring with greater severity of hypothyroidism [4]. In addition, TSH levels are reduced in prolonged critical illness, compared with the acute situation [21]. These findings suggest that a major change in thyroid hormone set point regulation may occur. Our observation indicates that even biochemical subclinical hypothyroidism causes severe clinical manifestations and the judgment of severity in subclinical hypothyroidism should be guided by clinical presentation and not only by serum TSH concentration.

The accumulation of fluid in serous body cavities in hypothyroidism is frequently recognized, the most common sites being the pleural, peritoneal and pericardial cavities. It was reported that pleural effusions secondary to hypothyroidism were small, noninflammatory effusions that have characteristics between transdates and exudates [6] and are frequently associated with marked ascites [19]. The precise mechanism by which these effusions develop is not well known. Parving et al. demonstrated the combination of increased extravasations of plasma proteins and lack of a compensatory increase in lymph flow and protein return rate [22], and suggested this as the cause of exudates in serous cavities. Lange demonstrated that the capillary permeability increased with leakage of plasma proteins in state of hypothyroidism and that the permeability rapidly returned to normal with thyroid hormone therapy [7]. Recently, elevation of VEGF has been reported in POEMS syndrome, which often accompanies extravascular volume overload [14]. VEGF induces a rapid and reversible increase in vascular permeability, and it is thought that these functions may cause the development of clinical manifestations, including ascites, pleural effusion, peripheral edema and organomegaly in this syndrome. An association of edema with increased VEGF levels has also been demonstrated in other pathological conditions, such as ovarian hyperstimulation syndrome [15], preeclampsia [16], and diabetic patients with troglitazone treatment [17]. In our case, VEGF was elevated in the initial course of the episode and was then reduced with improvement of pleural effusions and peripheral edema after thyroid hormone replacement therapy. Therefore, it seems that VEGF has, at least partly, contributed as a primary pathogenic factor of pleural effusions and peripheral edema in our case, as well as in POEMS syndrome. 
VEGF is known to be expressed in a number of normal adult tissues, including the kidney, lung, uterus, ovary, brain, heart, skin, pituitary gland, and macrophages [23]. It has been demonstrated in vitro that VEGF is produced by thyroid follicular epithelial cells in response to stimulation of the TSH receptor [24-27]. Secreted VEGF stimulates VEGF receptors (Flt family) on endothelial cells of thiouracil-fed rats in a TSHdependent paracrine mechanism, leading to proliferation of endothelial cells and hypervascularity of the thyroid gland $[24,26]$. Recently, Klein et al. demonstrated that recombinant human TSH (rhTSH) stimulation for 3 weeks induced local VEGF expression in normal human thyroid, which were grafted into nude mice [28]. Moreover, litaka et al. showed that serum VEGF levels are positively correlated with TSH levels in patients with Hashimoto's thyroiditis [29]. However, conflicting results have been reported both in vitro and in vivo [30-33]. Sorvillo et al. demonstrated that a short-term administration of rhTSH in patients induces a significant reduction in serum VEGF levels [31], whereas, Tuttle et al. did not observe any difference in serum VEGF levels in patients after short-term stimulation rhTSH [32]. Therefore, the duration of TSH stimulation in vivo may be critical in determining the response of VEGF production. Furthermore, Sorvillo et al. showed that TSH in vivo might be able to regulate VEGF production from many extrathyroidal tissues [31]. A possible explanation of this case is that VEGF might be increased by prolonged stimulation of TSH, and that it might then be produced from tissues other than the thyroid gland because her thyroid gland was atrophic. Secreted VEGF might subsequently stimulate VEGF receptors on endothelial cells, leading to increase in vascular permeability, and develop pleural effusions and peripheral edema.

In our patient, estrogen levels were increased in spite of being postmenopausal and decreased after thyroid hormone replacement. Thyroid hormone has been demonstrated to affect the clearance rate of estrogen and the peripheral aromatization of androgen [34, 35]. Longcope et al. demonstrated that hypothyroidism results in a decrease in the metabolic clearance rates of androstenedione (A) and estrone (E1), and an increase in peripheral aromatization of A to E1 [35]. The peripheral aromatization of androgens is a major source of estrogens in men and postmenopausal women, and an increase in peripheral aromatization might have led to the elevation of serum estrogen levels in our patient. An estrogen-responsive element in the promoter region of the gene for VEGF has been identified [36], that interacts with both ER- $\alpha$ and ER- $\beta$. Indeed, serum VEGF levels are higher in premenopausal women compared with postmenopausal women [37]. Furthermore, estrogen replacement therapy increased serum VEGF levels in postmenopausal women [37-39]. Therefore, increased estrogen, caused by hypothyroidism, also might have partially contributed to the elevation of serum VEGF levels in our patient.

In summary, we present a case of subclinical hypothyroidism with severe clinical manifestations. After thyroid hormone replacement therapy, elevated VEGF levels were decreased with improvement of pleural effusions and peripheral edema. Our observations indicate that even biochemical subclinical hypothyroidism causes severe clinical manifestations. Furthermore, these observations lead us to speculate that elevated VEGF may be a potential factor in the course of pathogenesis of pleural effusions and peripheral edema in hypothyroid patients.

\section{References}

1. McDermott MT, Ridgway EC (2001) Subclinical hypothyroidism is mild thyroid failure and should be treated. J Clin Endocrinol Metab 86: 4585-4590.

2. Chu JW, Crapo LM (2001) The treatment of subclinical hypothyroidism is seldom necessary. J Clin Endocrinol Metab 86: 4591-4599.

3. Surks MI, Ortiz E, Daniels GH, Sawin CT, Col NF, Cobin RH, Franklyn JA, Hershman JM, Burman KD, Denke MA, Gorman C, Cooper RS, Weissman NJ (2004) Subclinical thyroid disease: scientific review and guidelines for diagnosis and management. JAMA
291: 228-238.

4. Meier C, Trittibach P, Guglielmetti M, Staub JJ, Muller B (2003) Serum thyroid stimulating hormone in assessment of severity of tissue hypothyroidism in patients with overt primary thyroid failure: cross sectional survey. BMJ 326: 311-312.

5. Lindsay RS, Toft AD (1997) Hypothyroidism. Lancet 349: 413-417.

6. Gottehrer A, Roa J, Stanford GG, Chernow B, Sahn SA (1990) Hypothyroidism and pleural effusions. Chest 98: 1130-1132. 
7. Lange K (1944) Capillary permeability in myxedema. Am J Med Sci 208: 5-15.

8. Leung DW, Cachianes G, Kuang WJ, Goeddel DV, Ferrara N (1989) Vascular endothelial growth factor is a secreted angiogenic mitogen. Science 246: 13061309.

9. Keck PJ, Hauser SD, Krivi G, Sanzo K, Warren T, Feder J, Connolly DT (1989) Vascular permeability factor, an endothelial cell mitogen related to PDGF. Science 246: 1309-1312.

10. Ferrara N, Carver-Moore K, Chen H, Dowd M, Lu L, O'Shea KS, Powell-Braxton L, Hillan KJ, Moore MW (1996) Heterozygous embryonic lethality induced by targeted inactivation of the VEGF gene. Nature 380: 439-442.

11. Kim KJ, Li B, Winer J, Armanini M, Gillett N, Phillips HS, Ferrara N (1993) Inhibition of vascular endothelial growth factor-induced angiogenesis suppresses tumour growth in vivo. Nature 362: 841-844.

12. Senger DR, Galli SJ, Dvorak AM, Perruzzi CA, Harvey VS, Dvorak HF (1983) Tumor cells secrete a vascular permeability factor that promotes accumulation of ascites fluid. Science 219: 983-985.

13. Lobb RR, Key ME, Alderman EM, Fett JW (1985) Partial purification and characterization of a vascular permeability factor secreted by a human colon adenocarcinoma cell line. Int J Cancer 36: 473-478.

14. Watanabe O, Arimura K, Kitajima I, Osame M, Maruyama I (1996) Greatly raised vascular endothelial growth factor (VEGF) in POEMS syndrome. Lancet 347: 702 .

15. MuClure N, Healy DL, Rogers PA, Sullivan J, Beaton L, Haning RV Jr, Connolly DT, Robertson DM (1994) Vascular endothelial growth factor as capillary permeability agent in ovarian hyperstimulation syndrome. Lancet 344: 235-236.

16. Baker PN, Krasnow J, Roberts JM, Yeo KT (1995) Elevated serum levels of vascular endothelial growth factor in patients with preeclampsia. Obstet Gynecol 86: 815-821.

17. Emoto M, Anno T, Sato Y, Tanabe K, Okuya S, Tanizawa Y, Matsutani A, Oka Y (2001) Troglitazone treatment increases plasma vascular endothelial growth factor in diabetic patients and its mRNA in 3T3-L1 adipocytes. Diabetes 50: 1166-1170.

18. Dispenzieri A, Kyle RA, Lacy MQ, Rajkumar SV, Therneau TM, Larson DR, Greipp PR, Witzig TE, Basu R, Suarez GA, Fonseca R, Lust JA, Gertz MA (2003) POEMS syndrome: definitions and long-term outcome. Blood 10: 2496-2506.

19. Brown SD, Brashear RE, Schnute RB (1983) Pleural effusion in a young woman with myxedema. Arch Intern Med 143: 1458-1460.

20. Zulewski H, Muller B, Exer P, Miserez AR, Staub JJ (1997) Estimation of tissue hypothyroidism by a new clinical score: evaluation of patients with various grades of hypothyroidism and controls. J Clin Endocrinol Metab 82: 771-776.

21. Van den Berghe G, de Zegher F, Veldhuis JD, Wouters P, Gouwy S, Stockman W, Weekers F, Schetz M, Lauwers P, Bouillon R, Bowers CY (1997) Thyrotrophin and prolactin release in prolonged critical illness: dynamics of spontaneous secretion and effects of growth hormone-secretagogues. Clin Endocrinol (Oxf) 47: 599-612.

22. Parving HH, Hansen JM, Nielsen SL, Rossing N, Munck O, Lassen NA (1979) Mechanisms of edema formation in myxedema-increased protein extravasation and relatively slow lymphatic drainage. $N$ Engl $J$ Med 301: 460-465.

23. Ferrara N, Houck K, Jakeman L, Leung DW (1992) Molecular and biological properties of the vascular endothelial growth factor family of proteins. Endocr Rev 13: 18-32.

24. Sato K, Yamazaki K, Shizume K, Kanaji Y, Obara T, Ohsumi K, Demura H, Yamaguchi S, Shibuya M (1995) Stimulation by thyroid-stimulating hormone and Grave's immunoglobulin G of vascular endothelial growth factor mRNA expression in human thyroid follicles in vitro and flt mRNA expression in the rat thyroid in vivo. J Clin Invest 96: 1295-1302.

25. Soh EY, Duh QY, Sobhi SA, Young DM, Epstein HD, Wong MG, Garcia YK, Min YD, Grossman RF, Siperstein AE, Clark OH (1997) Vascular endothelial growth factor expression is higher in differentiated thyroid cancer than in normal or benign thyroid. $J$ Clin Endocrinol Metab 82: 3741-3747.

26. Viglietto G, Romano A, Manzo G, Chiappetta G, Paoletti I, Califano D, Galati MG, Mauriello V, Bruni P, Lago CT, Fusco A, Persico MG (1997) Upregulation of the angiogenic factors PlGF, VEGF, and their receptors (Flt-1, Flk-1/KDR) by TSH in cultured thyrocytes and in the thyroid gland of thiouracil-fed rats suggest a TSH-dependent paracrine mechanism for goiter hypervascularization. Oncogene 15: 2687-2698.

27. Hoffmann S, Hofbauer LC, Scharrenbach V, Wunderlich A, Hassan I, Lingelbach S, Zielke A (2004) Thyrotropin (TSH)-induced production of vascular endothelial growth factor in thyroid cancer cells in vitro: evaluation of TSH signal transduction and of angiogenesisstimulating growth factors. J Clin Endocrinol Metab 89: 6139-6145.

28. Klein M, Brunaud L, Muresan M, Barbe F, Marie B, Sapin R, Vignaud JM, Chatelin J, Angioi-Duprez K, Zarnegar R, Weryha G, Duprez A (2006) Recombinant human thyrotropin stimulates thyroid angiogenesis in vivo. Thyroid 16: 531-536.

29. Iitaka M, Miura S, Yamanaka K, Kawasaki S, Kitahama S, Kawakami Y, Kakinuma S, Oosuga I, Wada S, Katayama S (1998) Increased serum vascular endo- 
thelial growth factor levels and intrathyroidal vascular area in patients with Graves' disease and Hashimoto's thyroiditis. J Clin Endocrinol Metab 83: 3908-3912.

30. Miyagi E, Katoh R, Li X, Lu S, Suzuki K, Maeda S, Shibuya M, Kawaoi A (2001) Thyroid stimulating hormone downregulates vascular endothelial growth factor expression in FRTL-5 cells. Thyroid 11: 539-543.

31. Sorvillo F, Mazziotti G, Carbone A, Piscopo M, Rotondi M, Cioffi M, Musto P, Biondi B, Iorio S, Amato G, Carella C (2003) Recombinant human thyrotropin reduces serum vascular endothelial growth factor levels in patients monitored for thyroid carcinoma even in the absence of thyroid tissue. J Clin Endocrinol Metab 88: 4818-4822.

32. Tuttle RM, Fleisher M, Francis GL, Robbins RJ (2002) Serum vascular endothelial growth factor levels are elevated in metastatic differentiated thyroid cancer but not increased by short-term TSH stimulation. J Clin Endocrinol Metab 87: 1737-1742.

33. Schmid C, Brandle M, Zwimpfer C, Zapf J, Wiesli P (2004) Effect of thyroxine replacement on creatinine, insulin-like growth factor 1, acid-labile subunit, and vascular endothelial growth factor. Clin Chem 50: 228231.

34. Ridgway EC, Longcope C, Maloof F (1975) Metabolic clearance and blood production rates of estradiol in hyperthyroidism. J Clin Endocrinol Metab 41: 491-
497.

35. Longcope C, Abend S, Braverman LE, Emerson $\mathrm{CH}$ (1990) Androstenedione and estrone dynamics in hypothyroid women. J Clin Endocrinol Metab 70: 903907.

36. Hyder SM, Nawaz Z, Chiappetta C, Stancel GM (2000) Identification of functional estrogen response elements in the gene coding for the potent angiogenic factor vascular endothelial growth factor. Cancer Res 60: 3183-3190.

37. Agrawal R, Prelevic G, Conway GS, Payne NN, Ginsburg J, Jacobs HS (2000) Serum vascular endothelial growth factor concentrations in postmenopausal women: the effect of hormone replacement therapy. Fertil Steril 73: 56-60.

38. Zacharieva S, Atanassova I, Kirilov G, Kalinov K, Shigarminova R, Nachev E, Aslanova N (2002) Effect of transdermal estrogen therapy on some vasoactive humoral factors and 24-h ambulatory blood pressure in normotensive postmenopausal women. Climacteric 5: 293-299.

39. Christodoulakos G, Lambrinoudaki I, Panoulis C, Papadias C, Sarandakou A, Liakakos T, Alexandrou A, Creatsas G (2004) Effect of hormone therapy, tibolone and raloxifene on circulating vascular endothelial growth factor in Greek postmenopausal women. Eur J Endocrinol 151: 187-192. 